\title{
Mathematical modeling bringing the operation of air split-conditioners heat pumps to the same internal temperature conditions
}

\author{
Labay V. Yo., Yaroslav V. Yu., Dovbush O. M., Tsizda A. Ye. \\ Department of Heat, Gas Supply and Ventilation, Institute of Construction and Engineering Systems, \\ Lviv Polytechnic National University, \\ 12 S. Bandera Str., 79013, Lviv, Ukraine
}

(Received 20 November 2020; Revised 8 April 2021; Accepted 17 May 2021)

\begin{abstract}
Nowadays, the use of heat pumps (HP) of air split-conditioners in air conditioning and heating systems of small industrial, public and residential facilities is becoming more common. It is known that the nominal heat capacity of HP of air split-conditioners is given in catalogs or reference literature under standard outdoor temperature conditions, namely: outdoor air temperature $+7^{\circ} \mathrm{C}$, indoor air temperature $+21^{\circ} \mathrm{C}$. At the same time, manufacturers of air split-conditioners do not ensure that, regardless of the size of heating capacity, all air split-conditioners have the same internal temperature conditions, namely: the evaporation temperature of the refrigerant and its condensation temperature. In this case, the thermodynamic efficiency, which can be best assessed by the exergetic outputinput ratio (OIR) of different heating capacity of HP of air split-conditioners, is different; this, in our opinion, is incorrect. However, today there is a lack of mathematical models of bringing the operation of air split-conditioners HP to the similar internal temperature conditions, which will allow us to obtain the same exergetic OIR for different heating capacity of HP. To create the mathematical model of bringing the operation of HP of air split-conditioners to the equal internal temperature conditions, we have proposed them, namely: the evaporation temperature of the refrigerant $+0.7^{\circ} \mathrm{C}$ and its condensation temperature $+40^{\circ} \mathrm{C}$. Taking these temperatures on the basis of the heat balances of the HP evaporator and HP condenser of air split-conditioners, we obtained the dependences for calculating air flow rates on the evaporator and condenser, which respectively maintain the proposed temperatures.
\end{abstract}

Keywords: heat pump of air split-conditioner, exergy balance, exergy efficiency, equal internal temperature conditions.

2010 MSC: $80 \mathrm{~A} 10,80 \mathrm{~A} 20$

DOI: $10.23939 / \mathrm{mmc} 2021.03 .509$

\section{Introduction}

Nowadays, the use of heat pumps (HP) of air split-conditioners in air conditioning and space heating systems of small industrial, public and residential facilities is becoming more common [1-7]. However, heat pumps of air split-conditioners belong to energy-intensive equipment and, therefore, they need the increase in their energy efficiency, which can be achieved as perfectly as possible by conducting their exergetic analysis, i.e. the modern thermodynamic methods [8-18].

Exergetic analysis allows with sufficient scientific accuracy and at the same time more clearly determine the degree of perfection and sources of losses in the installations and their parts and finally find ways to improve them [16-18].

Therefore, the authors developed an exergetic method of analyzing the operation of one-stage steamcompressor freon heat pumps of air split-conditioners (without effective cooling of the compressor), which is adapted for these split-conditioners and described in detail in [18]. This method uses the principle scheme of the heat pump of air split-conditioners (Fig. 1a) and, accordingly, the construction of the processes of its work on the ( $p, i)$ diagram (Fig. 1b) as well as refrigerant freon-32 (R32) [19]. 
Calculation and quantitative experiments were performed using the computer program developed by the authors in Excel.

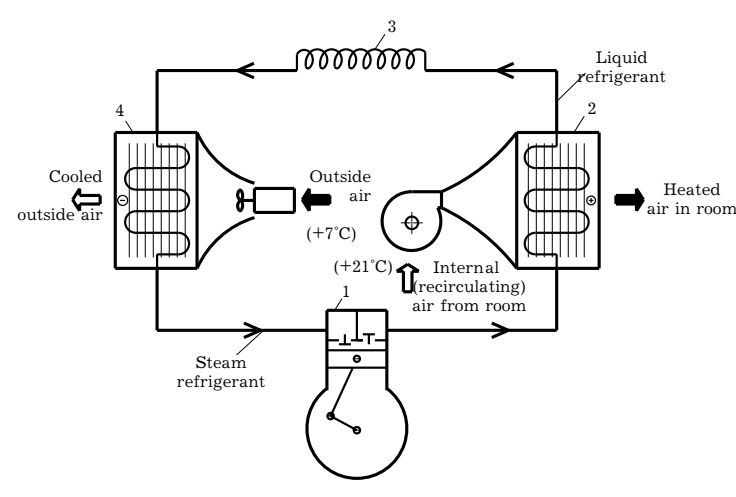

$a$

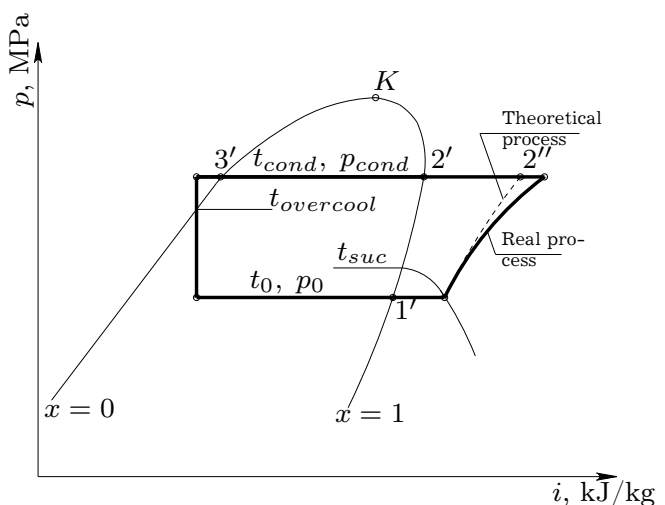

$b$

Fig. 1. Scheme of heat pump of air split-conditioner $(\boldsymbol{a})$ : 1 is compressor; 2 is condenser; 3 is capillary tube (throttle); 4 is evaporator and construction of the processes of its work on $(p, i)$ diagram $(\boldsymbol{b}): 1,2,3,4$ are characteristic points of the thermodynamic cycle of the heat pump.

At the same time, the authors noticed that manufacturers of heat pumps of air split-conditioners give their heat capacity in catalogs [20] or reference literature under standard external temperature conditions, which are determined by the ambient temperature (above (outside air) $t_{C_{1}}=+7^{\circ} \mathrm{C}$ and temperature of internal (recirculation) air $t_{H_{1}}=+21^{\circ} \mathrm{C}$, not taking into account that for different heat pumps the same standard internal temperature conditions of their operation, which are determined by the evaporation temperature of the refrigerant $t_{e v}$ and its condensation temperature $t_{\text {cond }}$, must be appropriate. And this, in our opinion, is incorrect and leads to different values of exergetic OIR and exergy losses in the elements of heat pumps at different heat capacities.

\section{Analysis of reference data and problem solving}

Successful application of the exergetic method of analysis for different technical systems, in particular of refrigerating machines of air split-conditioners, have been grounded in the works of R. K. Clausius, John W. Gibbs, G. Gouy, A. Stodola, J. Shargut, R. Petela and V. M. Brodyansky for their technical and economic optimization and our works [8-18]. We have adapted this method to the analysis of heat pumps of air split-conditioners [18] and used in this article.

It is known that the energy efficiency of heat pumps of air split-conditioners is due to the parameters of both external and internal temperature conditions and the type of refrigerant [19]. Therefore, to further increase the efficiency of heat pumps work of air split-conditioners, we considered heat pumps of different heat capacities from firm "Mitsubishi Electric", operating on R32 refrigerant, and calculated their manufacturer installed different internal temperature conditions and different exergetic OIR.

To bring the operation of heat pumps of air split-conditioners to the same internal temperature conditions, we have developed an appropriate mathematical model and proposed the same internal temperature conditions for pumps of different heat capacities, namely: evaporation temperature of the refrigerant $+0.7^{\circ} \mathrm{C}$ and its condensation temperature $+40^{\circ} \mathrm{C}$. Taking these temperatures based on the heat balances of the evaporator and condenser of the heat pump air split-conditioner, we obtained the dependences for calculating the air flow rate on the evaporator and condenser, which respectively support the proposed temperatures.

Therefore, based on the analysis of the available literature data, the reduction of energy consumption consumed by heat pumps of air split-conditioners can be achieved on the basis of the mathematical model developed by us to bring their work to the same internal temperature conditions. 


\section{Purpose and tasks of the investigation}

The purpose of this work is to bring the operation of heat pumps of air split-conditioners to the same internal temperature conditions and exergetic OIR by setting the appropriate air flow in the evaporator and condenser of air split- conditioners, such as "Mitsubishi Electric" with nominal heat capacities 3200, 4000, 5400, 5800, $8100 \mathrm{~W}$ under standard external temperature conditions on the R32 refrigerant.

To achieve this purpose, the following basic tasks have been formulated:

- set the proposed same internal temperature operating conditions for heat pumps of air splitconditioners company "Mitsubishi Electric", for example, the evaporation temperature of the refrigerant $t_{e v}=+0.7^{\circ} \mathrm{C}$, and the condensation temperature $-t_{\text {cond }}=+40^{\circ} \mathrm{C}$;

- determine the corresponding to the proposed internal temperature conditions of air flow on the evaporator and condenser heat pumps of air split-conditioners company "Mitsubishi Electric", under which the heat capacities of air conditioners will remain constant only under the same standard outdoor temperature conditions, and exergetic OIR for air conditioners different heat capacities will be the same.

\section{Methods, materials and results of researches}

Investigations of the results bringing the operation of heat pumps of air split-conditioners to the same internal temperature conditions and exergetic OIR are carried out on one-stage steam-compressor freon heat pumps of air split-conditioners (without effective cooling of the compressor), which applies to air split-conditioners, the scheme is shown in Fig. 1a, and described in article [18]. The operation of the heat pump and the calculation of energy efficiency based on the construction of its thermodynamic process of operation on $(p, i)$-diagram (Fig. 1b) are also given in the article [18].

The proposed air flow rate for the evaporator of the air conditioner was determined from the equation of its heat balance

$$
\begin{aligned}
L_{e v}^{\text {prop }} & =\frac{\left(Q_{C}^{\text {nom }}-W_{\text {cond }}^{\text {nom }} \cdot r \times 0.278\right) \times 3.6}{\left(t_{C_{1}}-t_{e v}^{\text {prop }}-\Delta t_{e v}\right) \cdot \rho_{\text {air }}^{e v} \cdot c_{a i r}} \\
& =\frac{\left(0.01 \cdot Q_{C}^{\text {nom }}-7.1 \cdot W_{\text {cond }}^{\text {nom }}\right) \cdot\left(273+t_{C_{1}}\right)}{t_{C_{1}}-t_{e v}^{\text {prop }}-\Delta t_{\text {ev }}}, \quad \mathrm{m}^{3} / \mathrm{h},
\end{aligned}
$$

and, accordingly, the proposed air flow for the condenser of the air conditioner - from the equation of its heat balance

$$
\begin{aligned}
L_{\text {cond }}^{\text {prop }} & =\frac{Q_{H}^{\text {nom }} \times 3.6}{\left(t_{\text {cond }}^{\text {prop }}-t_{1}-\Delta t_{\text {cond }}\right) \cdot \rho_{\text {air }}^{\text {cond }} \cdot c_{\text {air }}} \\
& =\frac{0.01 \cdot Q_{H}^{\text {nom }} \cdot\left(273+t_{1}\right)}{t_{\text {cond }}^{\text {prop }}-t_{1}-\Delta t_{\text {cond }}}, \quad \mathrm{m}^{3} / \mathrm{h},
\end{aligned}
$$

where $Q_{C}^{\text {nom }}$ is nominal cool capacity of the air split-conditioner, W [20]; $Q_{H}^{\text {nom }}$ is nominal heat capacity of the air split-conditioner, $\mathrm{W}[20] ; W_{\text {cond }}^{\text {nom }}$ is nominal precipitation of condensate on the evaporator of the air split-conditioner, $\mathrm{l} / \mathrm{h} ; r=2500 \mathrm{~kJ} / \mathrm{kg}$ is hidden specific heat of condensation of water vapor; $\Delta t_{e v}$ is accepted the final temperature difference in the evaporator of the air split-conditioner (air at the outlet of the evaporator $t_{C_{2}}$ and boiling refrigerant $\left.t_{e v}\right),{ }^{\circ} \mathrm{C} ; \rho_{\text {air }}^{e v}=353 /\left(273+t_{C_{1}}\right)$ is density of internal air entering the air split-conditioner evaporator, $\mathrm{kg} / \mathrm{m}^{3} ; c_{a i r}=1.005 \mathrm{~kJ} /(\mathrm{kg} \cdot \mathrm{K})$ is specific heat of air; $\Delta t_{\text {cond }}$ is accepted the final temperature difference in the condenser of the air split-conditioner (condensing refrigerant, $t_{\text {cond }}$ and air at the outlet of the condenser $\left.t_{2}\right),{ }^{\circ} \mathrm{C} ; \rho_{\text {air }}^{\text {cond }}=353 /\left(273+t_{1}\right)$ is density of the internal air that enters the evaporator of the air conditioner, $\mathrm{kg} / \mathrm{m}^{3}$.

Initially, the exergetic analysis of the operation of heat pumps of air split-conditioners of the company "Mitsubishi Electric" was carried out under standard external temperature conditions, for which the nominal cooling capacity $Q_{C}^{n o m}, \mathrm{~W}$; nominal precipitation of condensate on the evaporator 
$W_{\text {cond }}^{\text {nom }}, \mathrm{l} / \mathrm{h}$; nominal (installed) air flow in the evaporator $L_{e v}^{n o m}, \mathrm{~m}^{3} / \mathrm{h}$; nominal (installed) air flow in the condenser $L_{\text {cond }}^{\text {nom }}, \mathrm{m}^{3} / \mathrm{h}[20]$.

After that, on each of the same air split-conditioner successively changed the air flow rate on the evaporator $L_{e v}, \mathrm{~m}^{3} / \mathrm{h}$, according to formula (1), and respectively on the condenser $L_{\text {cond }}, \mathrm{m}^{3} / \mathrm{h}-$ according to formula (2) so that the internal temperature of the heat pumps air split-conditioners and their exergetic OIR coincided. So set $L_{e v}^{\text {prop }}$ and $L_{\text {cond }}^{\text {prop }}$.

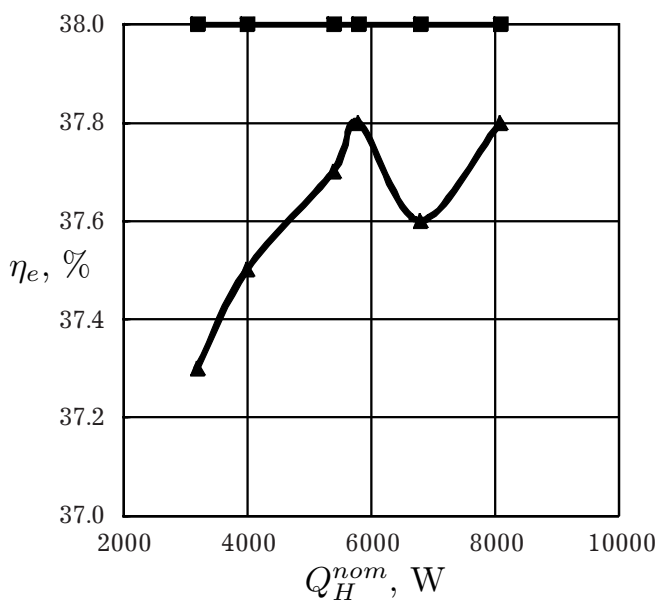

Fig. 2. Dependence of exergetic efficiency of air split-conditioners heat pumps of the company "Mitsubishi Electric" from their nominal cool capacity at nominal air flow in the evaporate and condenser $(\boldsymbol{\Lambda})$ and proposed
Other operating conditions of air conditioners are as follows:

- standard ambient temperature (outside air) $t_{C_{1}}=$ $+7^{\circ} \mathrm{C}$

- standard temperature of internal (recirculation) air according to ambient temperature $t_{H_{1}}=+21^{\circ} \mathrm{C}$;

- final temperature difference in the evaporator $\Delta t_{e v}=2.8^{\circ} \mathrm{C}$;

- final temperature difference in the condenser $\Delta t_{\text {cond }}=4.2^{\circ} \mathrm{C}$;

- difference of overheating temperatures in the evaporator $\Delta t_{\text {overheat }}=10^{\circ} \mathrm{C}$;

- difference of overcooling temperatures in the condenser $\Delta t_{\text {overcool }}=5^{\circ} \mathrm{C}$;

- adiabatic (indicator) compressor efficiency $\eta_{a d}=$ 0.8 ;

- electromechanical compressor efficiency $\eta_{e m}=0.9$.

The results of the calculations are given in Table 1 (in italics marked technical characteristics of heat pumps of air conditioners at standard external temperature conditions and nominal air flow rates on the evaporator and condenser, bold are those technical characteristics at standard external temperature conditions and for the proposed air flow rates on the evaporator and condenser), where $\eta_{e}$ is exergetic OIR of the air conditioner, and shown graphically in Fig. 2.

Table 1. The results of the calculations exergetic OIR of heat pumps air split-conditioners of the company "Mitsubishi Electric" at standard external temperature conditions $t_{\text {out }}=t_{C_{1}}=+7^{\circ} \mathrm{C} ; t_{\text {in }}=t_{H_{1}}=+21^{\circ} \mathrm{C}$ and nominal air flow rates on the evaporator and condenser and for the proposed.

\begin{tabular}{|c|c|c|c|c|c|c|c|}
\hline$L_{\text {cond }}, \mathrm{m}^{3} / \mathrm{h}$ & $L_{e v}, \mathrm{~m}^{3} / \mathrm{h}$ & $Q_{\text {heat }}^{\text {nom }}, \mathrm{W}$ & $N_{\text {cons }}^{\text {nom }}, \mathrm{W}$ & $Q_{\text {cool }}^{\text {nom }}, \mathrm{W}$ & $t_{\text {cond }},{ }^{\circ} \mathrm{C}$ & $t_{e v},{ }^{\circ} \mathrm{C}$ & $\eta_{e}$ \\
\hline 490 & 1020 & 3200 & 780 & 2500 & +44.4 & -0.52 & 0.373 \\
\hline $\mathbf{6 3 5}$ & $\mathbf{1 3 7 5}$ & $-"-$ & $-"-$ & $-"-$ & +40 & $+\mathbf{0 . 7 0}$ & $\mathbf{0 . 3 8 0}$ \\
\hline 585 & 1380 & 4000 & 1030 & 3500 & +45.3 & -0.37 & 0.375 \\
\hline $\mathbf{7 9 5}$ & $\mathbf{1 8 0 0}$ & $-"-$ & $-"-$ & $-"-$ & +40 & $+\mathbf{0 . 7 0}$ & $\mathbf{0 . 3 8 0}$ \\
\hline 630 & 1870 & 5400 & 1580 & 4200 & +50.4 & -0.49 & 0.377 \\
\hline $\mathbf{1 0 7 0}$ & $\mathbf{2 5 0 0}$ & $-"-$ & $-"-$ & $-"-$ & +40 & $+\mathbf{0 . 7 0}$ & $\mathbf{0 . 3 8 0}$ \\
\hline 615 & 2040 & 5800 & 1700 & 5000 & +52.9 & -0.42 & 0.378 \\
\hline $\mathbf{1 1 5 0}$ & $\mathbf{2 6 9 0}$ & $-"-$ & $-"-$ & $-"-$ & +40 & $+\mathbf{0 . 7 0}$ & $\mathbf{0 . 3 8 0}$ \\
\hline 925 & 2500 & 6800 & 1810 & 6100 & +46.8 & -0.41 & 0.376 \\
\hline $\mathbf{1 3 5 0}$ & $\mathbf{3 2 9 0}$ & $-"-$ & $-"-$ & $-"-$ & $+\mathbf{4 0}$ & $+\mathbf{0 . 7 0}$ & $\mathbf{0 . 3 8 0}$ \\
\hline 960 & 3000 & 8100 & 2230 & 7100 & +50.0 & -0.34 & 0.378 \\
\hline $\mathbf{1 6 1 0}$ & $\mathbf{3 8 9 0}$ & $-"-$ & $--^{\prime \prime}-$ & $-"-$ & +40 & $+\mathbf{0 . 7 0}$ & $\mathbf{0 . 3 8 0}$ \\
\hline
\end{tabular}

The minimum increase in exergetic OIR due to bringing the operation of heat pumps for air splitconditioners the company "Mitsubishi Electric" to the same internal temperature conditions with the highest heat capacity of $8100 \mathrm{~W}$ is:

$$
\Delta=\frac{0.380-0.378}{0.378} \cdot 100=0.53 \%,
$$


and the maximum (with the lowest heat output of $3200 \mathrm{~W}$ ) is:

$$
\Delta=\frac{0.380-0.373}{0.373} \cdot 100=1.9 \% \text {. }
$$

\section{Conclusions}

As a result of our investigation, it is proposed to recalculate the air flow rate on the evaporator and condenser of air split-conditioners on the example of air conditioners from the company "Mitsubishi Electric" to bringing their work to the same internal temperature conditions and exergetic OIR because, in our opinion, the design of air conditioners should be focused not only on external temperature conditions but also on internal ones.

Due to this, we have a general tendency to increase the exergetic OIR of air conditioners. However, to heat the air in the room, the current air conditioners recommend the use of one air conditioner with high heat capacity, rather than several with low, which have the lower exergetic OIR.

The given mathematical model of bringing the operation of heat pumps of air split-conditioners from the company "Mitsubishi Electric" to the same internal temperature conditions can be applied to different types of refrigerants and models of split-conditioners, provided that the thermodynamic properties of the refrigerant on which the air conditioner works and characteristics of the heat pump of the split-conditioner are known.

[1] Energy Strategy of Ukraine until 2030, http://www .ukrenergo.energy .gov .ua (in Ukrainian).

[2] Heat Pump, Types and Applications of Heat Pumps, http://www.ecosvit.net/ua/teplovij-nasos-vidi-ta zastosuvannya (in Ukrainian).

[3] Heat pumps, http://www.npblog.com.ua/index.php/hi-tech/teplovi-nasosi.html (in Ukrainian).

[4] Bezrodnyi M. N., Dranik T. V. Thermodynamic Efficiency of Heat Pump Application for Providing Comfortable Conditions in Indoor Swimming Pools. Eastern European Journal of Enterprise Technologies. 3 (8), 25-30 (2013), (in Ukrainian).

[5] Matsevityi Yu. M., Chirkin N. B., Bogdanovich A. S., Klepanda A. S. Introduction of Heat Pumping Technologies. Ecotechnology and Resource Saving. 3, 4-10 (2008), (in Russian).

[6] Zalewski P. K. Pompy ciepia. Podstawy teoretyczne i przykiady zastosowania. Kraków (1995), (in Polish).

[7] Morozyuk T. V. Theory of Refrigeration Machines and Heat Pumps. Odessa, Studio "Negotsiant" (2006), (in Russian).

[8] Szargut J., Petela R. Exergy. Moscow, Energy (1968), (in Russian).

[9] Sokolov E. Y., Brodyansky V. M. Energy Basis of Transformation of Heat and Cooling Processes. Moscow, Energoizdat (1981), (in Russian).

[10] Silvio de Oliveira Junior. Exergy. Production, Cost and Renewability. Springer (2013).

[11] Sazhin B. S., Bulekov A. P., Sazhin B. S. Exergy Analysis of Work of Industrial Plants: Monograph, Moscow (2000), (in Russian).

[12] Bejan A. Advanced Engineering Thermodynamics. placeStateNew York: John Wiley \& Sons (1988).

[13] Bejan A., Tsatsaronis G., Moran M. Thermal Design and Optimization. New York, J. Wiley (1996).

[14] Morosuk T., Nikulshin R., Morosuk L. Entropy-Cycle Method for Analysis of Refrigeration Machine and Heat Pump Cycles. Thermal Science. 10 (1), 111-124 (2006).

[15] Tsatsaronis J. The Interaction of Thermodynamics and Economy to Minimize Cost of Energy Conversion Systems. Odessa, Studio "Negotsiant" (2002), (in Russian).

[16] Labay V., Dovbush O., Yaroslav V., Klymenko H. Mathematical Modeling of a Split-conditioner Operation for Evaluation of Exergy Efficiency of the R600A Refrigerant Application. Mathematical Modeling and Computing. 5 (2), 169-177 (2018). 
[17] Labay V. Yo., Mysak Yo. S. Bringing the Work of Air Split-conditioners Refrigeration Machines to the Same Internal Temperature. Refrigeration Engineering and Technology. 4 (126), 19-22 (2010), (in Ukrainian).

[18] Labay V. Yo., Yaroslav V. Yu., Dovbush O. M., Tsizda A. Ye. Mathematical Modeling of an Air SplitConditioner Heat Pump Operation for Investigation its Exergetic Efficiency. Mathematical Modeling and Computing. 7 (1), 169-178 (2020).

[19] Jakobsen A., Rassmussen B.-D., Skovrup M.-J., Andersen S.-E. CoolPack - a collection of simulation tools for refrigeration - Tutorial - Version 1.46. - Department of Energy Engineering Technical University of Denmark (2001).

[20] Mitsubishi Electric Catalog Split (2019).

\title{
Математичне моделювання приведення роботи теплових помп split-кондиціонерів до однакових внутрішніх температурних умов
}

\author{
Лабай В. Й., Ярослав В. Ю., Довбуш О. М., Цізда А. Є. \\ Кафедра теплогазопостачання $і$ вентиляиї, \\ Інститут будівництва та інженерних систем, \\ Начіональний університет "Львівсъка політехніка", \\ вул. С. Бандери, 12, 79013, Львів, Україна
}

\begin{abstract}
Нині стає все розповсюдженішим використання теплових помп (ТП) повітряних splitкондиціонерів у системах кондиціювання та опалення приміщень невеликих промислових, громадських та житлових об'єктів. Відомо, що номінальна теплопродуктивність ТП повітряних split-кондиціонерів наводиться у каталогах чи довідковій літературі за стандартних зовнішніх температурних умов, а саме: температурі зовнішнього повітря $+7^{\circ} \mathrm{C}$, внутрішнього у приміщенні $-+21^{\circ} \mathrm{C}$. У той самий час виробники split-кондиціонерів не дотримуються того, щоб незалежно від розміру теплопродуктивності всі split-кондиціонери мали однакові внутрішні температурні умови, а саме: температуру випаровування холодильного агента і його температуру конденсації. У цьому випадку термодинамічна ефективність, що найдосконаліше оцінюється за ексергетичним ККД різних за теплопродуктивністю ТП повітряних split-кондиціонерів, $\epsilon$ неоднаковою, що на нашу думку є некоректним. Але на сьогоднішній день бракує математичної моделі приведення роботи ТП повітряних split-кондиціонерів до однакових внутрішніх температурних умов, яка дасть можливість отримати для різних за теплопродуктивністю ТП однаковий ексергетичний ККД. Для створення математичної моделі приведення роботи ТП повітряних split-кондиціонерів до однакових внутрішніх температурних умов нами вони запропоновані, а саме: температура випаровування холодильного агента $+0.7^{\circ} \mathrm{C}$ і його температура конденсації $+40^{\circ} \mathrm{C}$. Приймаючи ці температури на основі теплових балансів випарника і конденсатора TП split-кондиціонера, нами отримані залежності для підрахунку витрат повітря на випарнику і конденсаторі, що відповідно підтримують запропоновані температури.
\end{abstract}

Ключові слова: теплова помпа split-кондиціонера, ексергетичний баланс, ексергетична ефективність, однакові внутрішні температурні умови.

Mathematical Modeling and Computing, Vol. 8, No.3, pp. 509-514 (2021) 